\title{
MENGEMBANGKAN NILAI KARAKTER DAN KEMAMPUAN 4C ANAK MELALUI PENDIDIKAN SENI TARI DI MASA REVOLUSI INDUSTRI 4.0
}

\author{
Aris Setiawan \\ Universitas Muhammadiyah Surabaya \\ wedangmusik@gmail.com
}

\begin{abstract}
ABSTRAK
Pada prinsipnya pendidikan merupakan landasan dasar dalam merubah perilaku menuju kebaikan. Oleh karena itu diperlukan usaha untuk menanamkan pendidikan sejak dini bagi anak. Maka hal yang perlu dilakukan sebagai dasar dalam membekali anak yaitu melalui pendidikan karakter. Dengan pendidikan karakter akan memberikan pembelajaran bagi anak dalam mempersiapkan kehidupannya di masa mendatang. Untuk memberikan pembelajaran tentang karaker dapat melalui pendidikan seni tari. Melalui Pendidikan seni tari, anak bisa belajar tentang nilai karakter yang terdapat di dalamnya. Selain itu juga, dengan pendidikan seni tari dapat mengembangkan kemampuan 4C dalam menghadapi tantangan di masa revolusi industri 4.0 ini.
\end{abstract}

Katakunci: Pendidikan seni tari, karakter, kemampuan 4C, revolusi Industri 4.0

\section{ABSTRACT}

In principle education is the basic foundation in changing behavior towards goodness. Therefore, an effort is needed to instill early education for children. Then the thing that needs to be done as a basis in equipping children is through character education. Character education will provide learning for children in preparing for their future lives. To provide learning about character skills through dance education. Through dance education, children can learn about the value of the characters contained in it. In addition, dance education can develop 4C's ability to face challenges in this industrial revolution 4.0.

Keywords: Dance arts education, character, 4C ability, Industrial revolution 4.0

\section{PENDAHULUAN}

Pendidikan merupakan wadah atau tempat bagi manusia untuk memperoleh berbagai ilmu pengetahuan. Melalui pendidikan manusia dapat berpikir dalam mencapai harapan yang diinginkannya. Tentu semua itu melalui proses panjang yang memberikan ruang pada manusia untuk belajar sesuai kebutuhannya. Di sisi lain, pendidikan juga dapat dimaknai sebagai upaya dalam menjadikan manusia lebih maju.

Pada dasarnya pendidikan adalah ruang bagi manusia untuk mengubah kehidupan yang lebih layak. Baik itu terkait dengan mempersiapkan pekerjaan, mampu berpikir kreatif maupun menyiapkan mental dalam menghadapi segala persoalan yang dihadapi. Oleh karena itu pentingnya pendidikan sebagai landasan dasar untuk menghadapi tantangan tersebut. Menjadikan manusia semakin cerdas serta membangun watak yang beradab.

Pada awalnya pendidikan diberikan pada ruang keluarga yang secara proses memberikan pembelajaran positif. Lihat saja anak yang masih belum bisa memegang 
sendok tentu akan diajarkan cara yang tepat. Begitu juga anak belum bisa bicara maka akan diajarkan cara bicara yang tepat dan benar. Selain itu keluarga juga memberikan pendidikan yang terkait dengan budi pekerti yang menyangkut tentang perilaku yang baik dan buruk. Keluarga sebagai lembaga pertama menginginkan bahwa anak-anak yang diajarkan dapat berbuat baik..

Maka peran keluarga dalam membangun pendidikan sangat penting dan berguna bagi perkembangan anak di masa mendatang. Membangun nilai positif yang nantinya sangat berguna dalam memberikan pengetahuan, keterampilan maupun perilaku yang baik. . Menyadarkan betapa pentingnya arti pendidikan dengan cara yang dianut dan diyakini keluarga dalam membentuk manusia yang berarti.

Selain keluarga pendidikan berikutnya di dapat dari masyarakat yang tentunya sangat luas sekali. Pada kehidupan masyarakat ada suata tatanan nilai yang harus diterapkan. Tatanan nilai itu biasanya hasil kesepakatan bersama sebagai hasil dari musyawarah dan pada akhirnya menjadi aturan dalam kehidupan bermasyarakat. Bagaimana berperilaku, bersikap dan bertindak sesuai tatanan nilai yang menjadi aturan bersama itu ditaati. Inilah pendidikan masyarakat yang lebih mementingkan kebersamaan dalam membangun budaya yang baik sebagai hasil dari kesepakatan bersama.

Berikutnya pendidikan yang memberikan ruang adalah sekolah sebagai lembaga formal. Pendidikan sekolah ini mempunyai tujuan tertentu dalam menghasilkan capain sesuai dengan kepentingan lembaganya. Maka pendidikan sekolah ini dirancang sangat stuktur sekali. Ada suatu perencanaan dalam proses pembelajarannya sehingga dalam pelaksanaannya sudah terkonsep. Pada pendidikan sekolah hal-hal yang berkaitan dengan pengetahuan, keterampilan dan perilaku menjadi pembelajaran dalam kesehariannya. Hal ini untuk memberi pengalaman bagi peserta didik untuk mendapatkan berbagai ilmu yang sangat beragam.

Pada hakikatnya pendidikan itu adalah menjadikan manusia lebih baik, terhormat dan terpuji. Untuk mencapai itu maka jadikan pendidikan sebagai landasan dasar dalam memanusiakan manusia. Artinya bagaimana pendidikan itu diterapkan dalam kehidupan yang bermakna. Menjadi manusia berpengetahuan, berketerampilan dan berperilaku tidak hanya untuk dirinya sendiri tetapi juga untuk orang lain. Semua itu perlu diterapkan tetapi bukan sekedar teori saja. Perlu ada tindakan nyata sebagai wujud dari perilaku yang akan dilakukan.

Undang Undang Sisdiknas tahun 2003 menyatakan bahwa 
pendidikan adalah usaha sadar dan terencana untuk mewujudkan suasana belajar dan proses pembelajaran agar peserta didik secara aktif mengembangkan potensi dirinya untuk memiliki kekuatan spritual keagamaan, pengendalihan diri, kepribadian, kecerdasan, akhlak mulia, serta keterampilan yang diperlukan dirinya, masyarakat, bangsa dan negara. Melihat hal itu, pendidikan sangat kompleks yang memberikan ruang untuk menyiapkan diri di kehidupan mendatang. Potensi yang dimiliki setiap anak dapat dikembangkan sesuai dengan bakat dan minatnya. Ini berarti pendidikan menyiapkan anak untuk berkembang dalam menyongsong kehidupan yang akan datang. Tentunya yang perlu di ajarkan pada anak-anak yaitu menumbuhkan karakter sebagai bekal utama dalam pendidikan.

Pada perkembangannya pendidikan selalu menghasilkan halhal yang baru salah satunya teknologi. Teknologi merupakan bagian dari kehidupan yang secara berkala selalu menghasilkan inovasiinovasi. Jika ditarik kebelakang, munculnya revolusi industri di Inggris pada abad 18 , salah satunya adalah menghasilkan mesin-mesin baru untuk kebutuhan pabrik. Pada saat itu kaum kapitalis atau bermodal menggunakan mesin untuk menggantikan tenaga manusia dalam menjalankan tugasnya. Mesin digunakan untuk mempermudah dan dapat menghasilkan keuntungan yang lebih banyak.

Di jaman ini sekarang dikenal dengan istilah revolusi industri 4.0 yang dalam percepatan teknologinya lebih canggih. Muncullnya alat telekomunikasi seperti hand phone yang mempunyai berbagai aplikasi misalnya. Ini membuat semua dapat dipermudah dalam mencapai yang diinginkan. Misal berbicara jarak jauh menggunakan video call, antara penelpon dan yang ditelpon bisa bertatap muka. Kemudian ramainya game on line yang menjadi kesenangan bagi anak-anak dan orang dewasa. Ini menunjukkan bahwa teknologi semakin canggih dalam peradaban dunia saat ini.

Teknologi membuat manusia menjadi kebutuhan bahkan boleh dikatakan kecanduan. Setiap hari tidak bisa lepas dari hanp phone, apa itu untuk pekerjaan atau hanya isengiseng saja. Ini berarti teknologi dapat menguasai manusia dalam menjalankan perilaku yang dilakukan. Bahkan sampai pada anak-anak yang tidak dipisahkan dengan hanp phone yang menjadikan kebutuhan penting bagi dirinya. Terkadang bangun tidur yang dicari handphonenya atau ketika alat itu tertinggal di rumah jadi gelisah. Sepertinya alat ini sudah menjadi kebiasaan bahkan kebudayaan yang mentradisi di jaman ini.

Begitulah teknologi yang selalu bisa menjalankan tugasnya sesuai kebutuhan yang diinginkan. 
Disamping sebagai alat pekerjaan, permainan teknologi juga memberikan pengetahuan. Pengetahuan dari hasil berpikir dalam menghasilkan gagasan yang kemudian dipakai dalam kehidupan manusia. Selain itu, teknologi juga merupakan hasil peradaban yang maju dalam memenuhi kebutuhan hidup manusia. Termasuk dapat digunakan dalam mengembangkan nilai karakter. Nilai yang sangat tepat untuk diajarkan pada sejak anak sejak dini.

Tentu pembelajaran yang terkait dengan karakter sangat penting bagi anak, hal ini sebagai pengalaman hidup agar dapat dipraktikkan dalam kehidupan seharihari. Pendidikan seni tari mewadahi itu semua dalam mewujudkan nilai karakter yang menjadi pembelajaran. Anak tidak hanya sekedar belajar tentang pemahaman tari dan praktik menari tetapi dibalik itu semua ada hal yang lain yang menyangkut karakter pada anak. Dengan demikian dapat memberi dampak pada perilaku kebaikan diri anak.

Pendididkan seni tari sepintas dilihat hanya belajar tentang pengetahuan dan belajar menari saja. Namun banyak hal banyak didapat termasuk dalam mengembangkan kemampuan 4C (community.critikal thinking, colaborasi and creativitas). Kemampun yang terkait dengan $4 \mathrm{C}$ sangat dibutuhkan bagi anak-anak. Artinya ini perlu dikembangkan pada anak agar mempunyai kemampuan itu. Sejak dini kemampuan $4 \mathrm{C}$ dapat diberikan pada anak agar dapat belajar tentang berbagai hal. Ini akan memberikan dampak yang baik untuk proses kehidupan anak di masa mendatang. Dengan begitu persiapan hidup pada anak dapat dimulai atau diajarkan pada masa pertumbuhan dan perkembangannya.

Pada masa pertumbuhan dan perkembangan anak sangat perlu dirangsang pada hal-hal yang positif. Memberikan pengetahuan dan pemahaman yang baik akan perilaku dalam kehidupan. Kemampuan 4C adalah salah satu modal dalam berkehidupan yang dapat menghasilkan pengetahuan secara pribadi dan dapat digunakan dalam bermasyarakat. Melalui pendidikan seni tari kemampuan 4C itu dapat diperoleh dengan cara-cara yang menyenangkan. Memberikan pembelajaran dengan bersenangsenang tetapi ada makna yang berarti bagi anak.

\section{METODE PENELITIAN}

Penelitian ini merupakan jenis penelitian studi literatur dengan mencari referensi teori yang relevan terhadap kasus atau permasalahan yang ditemukan. Referensi teori yang diperoleh dengan jalan penelitian studi literatur dijadikan sebagai pondasi dasar dan alat utama bagi praktik penelitian di lapangan.

Referensi dalam penelitian ini dicari dari buku, jurnal, artikel laporan penelitian, dan situs-situs di 
internet sehingga terkoleksi referensi yang relevan dengan perumusan masalah.

\section{PEMBAHASAN}

\section{Pendidikan Seni Tari dan Karakter}

Berbicara tentang

pendidikan seni tari maka terkait dengan pengetahuan tentang tari dan keterampilan menari. Pendidikan seni tari pada hakikatnya memberikan ruang bagi anak untuk berekspresi dalam mengembangkan pengetahuan serta bakat dan minatnya. Melalui pendidikan seni tari anak tidak hanya terampil menari tetapi juga dapat menambah wawasannya. Menurut Soedarsono (1972), tari adalah ungkapan jiwa manusia yang diekspresikan lewat gerak yang ritmis dan indah. Ini artinya bahwa tari adalah kegiatan sadar manusia yang secara sengaja ingin mengungkapkan persasaannya melalui gerak berirama dan mempunyai unsur keindahan.

Tari sebagai salah cabang seni memiliki ciri khas tersendiri dalam pengungkapannya. Melalui gerak, tari diekspresikan guna memperoleh keindahan bentuk pada penyajiannya. Pada awalnya tari digunakan sebagi sarana ritual dan dalam perkembangannya menjadi hiburan. Ini artinya bahwa tari sangat dibutuhkan dalam masyarakat guna memenuhi kebutuhan yang diiingkannya. Apakah sebagai sarana upacara ritual atau hiburan saja. Semua itu tergantung dari tujuan yang ingin dicapai.

Pada perkembangannya tari menjadi ilmu yang dipelajari di sekolah maupun perguruan tinggih. Maka ketika itu tari digunakan sebagai proses pembelajaran yang pada akhirnya memasuki ranah dunia pendidikan. Ini menunjukkan bahwa tari menjadi ilmu tersendiri yang dapat memberikan pembelajaran bagi anak-anak. Melalui pendidikan seni tari segala yang menyangkut persoalan tari dapat dipelajari. Tentu ini menjadi kemajuan dalam dunia pendidikan yang tidak hanya mempelajari persoalan-persoalan yang berkaitan dengan ilmu eksak saja. Pendidikan seni tari pada umumnya diperkenalkan sejak dini melalui belajar menari yang dilaksanakan di sekolah taman kanak-kanak. Pada proses pembelajarannya anak-anak diajarkan dengan bentuk-bentuk gerak sederhana agar bisa menyerap dari apa yang diberikan. Menyesuaikan dengan tingkat pertumbuhan dan perkembangan anak agar bentuk tari yang diberikan dapat dipelajari dan dilakukan. 
Tentunya ini memberikan ruang bagi anak untuk dapat mengekspresikan

kegembiraannya melalui seni tari.

Melalui pendidikan seni tari sangat berarti bagi anak dalam mengungkapkan ekspresinya melalui gerak-gerak yang berirama dan mempunyai unsur keindahan. Melalui pendidikan seni tari anak belajar tentang banyak hal. Baik itu terkait dengan keterampilan menari, pengetahuan tentang tari maupun hal-hal di luar tari. Apa yang ditampilkan dalam menari memang terlihat bentuknya saja. Namun demikian ada hal yang lain yang bisa memberikan pembelajaran bagi anak. Salah satunya adalah membentuk karakter yang positif bagi perkembangan anak.

Karakter terkait dengan kepribadian yang membawa anak pada perilaku dalam kehidupan. Tumbuhnya karakter dapat dipengaruhi oleh pengetahuan dan penilaian terhadap pengalaman. Dari situlah akan muncul karakter yang berpijak dari pengetahuan dan pengalaman hidup. Misal pengalaman hidup bersama keluarga yang menghasilkan pengetahuan. Pengaruhpengaruh itulah yang memberi dampak pada pembentukan karakter yang dipengaruhi dari lingkungangan kecilnya.
Proses pembentukan karakter memerlukan waktu panjang karena itu disitu ada pola pembiasaan yang harus diulangulang. Maka pola asih, asuh adalah cara yang tepat dalam membentuk karakter anak sejak dini. Dengan demikian akan memberi dampak pada anak untuk selalu melakukan hal-hal yang menjadi pembiasaan. Menurut Prof. Dr. Quraisy shihab (Purwanto, 2016:X) karakter terbentuk melalui perjalanan hidup seseorang. la dibangun oleh pengetahuan, pengalaman serta penilaian terhadap pengalaman. Kepribadian dan karakter yang baik merupakan interaksi seluruh totalitas manusia. Totalitas yang dirangsang dari pengaruhpengaruh positif.

Usaha dalam pembentukan karakter yang baik tentu dapat dimaknai sebagai bentuk memajukan anak. Dengan begitu akan tumbuh manusia yang berguna dan bermanfaat untuk dirinya sendiri dan orang lain. Betapa pentingnya bagi anak untuk mendapatkan pelayanan yang tepat agar menjadi modal dalam kehidupannya. Membentuk karakter yang baik demi kepentingan yang bermakna dalam memahami arti kehidupan nyata ini. Sangatlah berati bagi anak untuk ditanamanlan karakter yang positif untuk 


$$
\begin{aligned}
& \text { menumbuhkan perilaku pada } \\
& \text { kehidupan }
\end{aligned}
$$

Karakter terkait dengan nilai yang dapat menuntun anak pada jalan kebajikan.

Berikut ini nilai-nilai karakter yang dibangun dalam naskah kebijakan pendidikan karakter 2010 (Acetylena, 2018:78):

a. Karakter yang bersumber dari olah hati, antara lain beriman dan bertakwa, jujur, tertib, taat aturan, bertanggung jawab, bereempati, berani mengambil resiko, pantang menyerah, rela berkorban dan berjiwa patriotik.

b. Karakter yang bersumber dari olah pikir antara lain cerdas, kritis, kreatif, inovatif, ingin tahu, produktif, berorientasi ipteks dan reflektif.

c. Karakter yang bersumber dari olah raga/kinestetik antara lain bersih dan sehat, sportif, tangguh, andal, berdaya tahan, bersahabat, kooperatif, dterminatif, kompetitif, ceria dan gigih.

d. Karakter yang bersumber dari olah rasa dan karsa antara lain kemanusiaan, saling menghargai, gotong royong, kebersamaan, ramah, hormat, toleran, nasionalis, peduli, kosmopolit (mendunia), mengutamakan kepentingan umum. Cinta tanah air (patriotis), bangga menggunakan bahasa dan produk Indonesia, dinamis, kerja keras dab beretos kerja.

Apa yang terdapat pada naskah kebijakan pendidikan karakter itu, menunjukkan bahwa nilai itu sangat beragam. Sudang barang tentu nilai-nilai itu terdapat pada manusia, persoalannya apakah nilai itu ditanamkan atau tidak. Jika nilai itu menjadi pembiasaan maka akan menghasilkan hal kebaikan. Begitu sebaliknya jika nilai itu ditinggalkan akan menjadi keburukan. Maka perlu upaya dalam mengembangkan nilai itu yang pada akhirnya menjadi bagian dari karakter. Menurut Bertens (2002:139) bahwa nilai merupakan sesuatu yang menarik bagi kita, sesuatu yang kita cari, sesuatu yang menyenangkan, sesuatu yang disukai dan di inginkan, singkatnya sesuatu yang baik. Ini artinya bahwa nilai selalu mempunyai konotasi positif. Walaupun ada nilai yang negatif juga. Untuk memperbandingkan nilai positif dan negatif maka perlunya fakta dan inilah yang akan memperjelas nilai itu digunakan. Apakah untuk perbuatan kebaikan atau keburukan.

Untuk mencapai nilai yang berarti atau nilai kebaikan perlu dibangun karakter yang sangat terkait dengan pribadi seseorang. Hal ini dapat dimulai dari masa 
pendidikan anak-anak yang sangat tepat dalam memberikan pembelajaran tersebut. Melalui pendidikan seni tari diharapkan dapat memberikan sumbangan bagi anak untuk masa depannya. Seni tari yang merupakan bagian dari salah satu cabang seni memiliki ciri khas tersendiri dalam penyampainnya.

Seni dapat dimaknai sebagai kemampuan maupun keterampilan yang mempunyai tujuan estetis. Namun sebetulnya tidak itu saja ada tujuan lainnya yang terdapat dalam seni. Menurut Mulyani (2016) seni tidak hanya bertujuan mencapai nilai estetis tetapi juga terdapat nilai praktis dan etis. Ini menandakan bahwa seni tidak hanya untuk kepentingan estetis saja namun ada hal lainnya yang dapat dipelajari. Termasuk dalam pendidikan seni tari yang dapat membentuk karakter anak untuk lebih baik.

Melalui Pendidikan seni tari nilai karakter itu bisa diwujudkan seperti membangun percaya diri, keberanian, pantang menyerah, rasa sosial, dan tanggung jawab. Hal ini dapat terlihat ketika pembelajaran tari itu berlangsung. Begitu juga ketika penyajian tari itu ditampilkan nilai karakter itu akan nampak. Walaupun secara kasat mata yang terlihat gerak estetisnya saja namun ada nilai-nilai lain yang terbangun. Ini menunjukkan bahwa nilai yang terdapat pada pendidikan seni tari itu sangat kompleks.

\begin{tabular}{rr}
\multicolumn{2}{c}{ Pertanyaanya } \\
bagaimana nilai itu dapat \\
dibuktikan secara logis, baiklah
\end{tabular}
jika melihat anak belajar tari atau pada saat menari maka akan timbul percaya diri. Proses dalam menumbuhkan rasa percaya diri tentu tidak langsung terealisasi, namun melalui waktu panjang yang pada akhirnya rasa percaya diri itu tumbuh. Mulai dari menghafalkan setiap gerakan sampai pada bentuk tari yang utuh. Demikian juga dengan cara mengungkapkan tarian secara ekspresif. Di saat itulah rasa percaya diri itu nampak sebagai bentuk ungkapan alamih yang terbangun dari kesadaran dalam melakukan gerakan.

Rasa percaya diri dibangun dari proses yang tidak secara tibatiba, namun ada rentang waktu yang membuat nilai karakter itu muncul. Dari yang tidak bisa menjadi bisa, dari yang malu menjadi tidak malu, dari yang tidak ekspresif menjadi ekspresif. Inilah perjalanan dalam membangun percaya diri yang tentunya sangat berarti bagi perkembangan anak. Kemampuan menguasai diri sendiri dalam membentuk nilai karakter yang positif pada anak akan bisa menjadi bekal dalam 
kehidupan di masa mendatang. Pendidikan seni tari sebagai bagian dalam membangun karakter anak diharapkan mampu menghasilkan kualitas yang bermakna. Menjadikan anak membangun kesadarannya untuk dapat digunakan dalam kehidupan sehari-hari.

Di samping percaya diri, menumbuhkan keberanian yang positif juga dapat terlihat pada pendidikan seni tari. Hal ini bisa dilihat ketika anak menampilkan bentuk tari itu secara utuh. Ada semacam nilai karakter yang muncul yaitu menumbahkan rasa keberanian dalam menunjukkan tariannya. Gerakan demi gerakan dilakukan untuk ditunjukkan pada orang lain. Seperti terlihat pada pementasan yang tentutanya banyak penonton yang melihat. Anak diuji mentalnya dalam menghadapi banyak orang. Disitulah keberanian menjadi modal utama untuk ditunjukkan sebagai penguatan pada dirinya. Rasa malu mulai ditinggalkan demi kepentingan penampilan yang baik.

Pada prinsipnya keberanian merupakan hal yang sang penting bagi pembelajaran anak dalam menghadapi tantangan kehidupan. Tentu yang dimaksud keberanian disini adalah anak mampu menunjukkan dan menghadapi persoalan yang terjadi pada dirinya. Baik itu terkait dengan persoalan hidup atau menunjukkan kemampuan untuk tujuan positif. Untuk itulah keberanian menjadi pembelajaran bagi anak untuk bisa diterapkan pada kehidupan bermasyarakat. Dengan begitu anak sudah siap dalam menghadapi tantangan pada kehidupannya.

Nilai karakter yang lainnya pada pendidikan seni tari yaitu pantang menyerah. Pada nilai ini terlihat ketika anak belum hafal gerakan. Disitulah ada usaha yang dilakukan anak untuk berupaya menghafalkan gerakan yang dipelajarinya. Secara bertahap anak terus berupaya belajar gerak tari sampai pada bentuk yang utuh. Ada semacam pencarian gerak yang terus dilakukan hingga sampai pada pencapaian yang diinginkannya. Dari situlah nilai karakter yang terkait dengan pantang menyerah terlihat. Anak terus berjuang untuk bisa melakukan gerakan tari sampai mencapai tingkat kesempurnaan.

Pantang menyerah dapat dimaknai sebagai motivasi dari dalam diri yang biasa menguatkan pribadi anak. Dengan kegigihan anak diajarkan untuk tidak patah semangat, selalu berusaha dalam mencapai apa yang diinginkannya. Pendidikan seni tari mengajarkan pada hal itu sebagai penguatan 
untuk selalu berupaya dalam mencapai hasil maksimal. Pada pembelajarannya, anak diusahakan untuk terus berlatih samapai pada hasil yang dicapai. Untuk itulah nilai karakter yang menyangkut tentang pantang menyerah harus terus dibiasakan sehingga anak akan terus berusaha secara maksimal.

Kemudian rasa sosial juga menjadi nilai karakter pada pendidikan seni tari. Ini nampak pada tari kelompok yang mengutamakan kebersamaan dalam mengungkan pola gerak dan ruang pada satu pementasan. Ada komunikasi yang dibangun yaitu terjadinya pola gerak yang sama sehingga dapat dilihat sangat indah. Di saat latihan anak yang mampu memberikan contoh pada yang kurang mampu dalam menggerakkan gerak tarinya. Itu artinya ada rasa sosial yang dibangun dalam memberikan pengetahuan antar teman. Komunikasi antar teman dalam membangun kebersamaan terjadi untuk menghasilkan gerakan yang sama, serempak dan kompak.

Melalui pendidikan seni tari anak diajarkan pada nilai-nilai sosial yang sangat berguna pada perkembangannya. Asrori (2007:36) berpendapat gejala yang tampak pada aspek sosial antara lain:

a. Semakin berkembangnya sifat toleran, empati serta memahami dan menerima pendapat orang lain.

b. Semakin santun dalam menyampaikan pendapat dan kritik kepada orang lain.

c. Adanya keinginan untuk selalu bergaul dengan orang lain dan bekerja sama dengan orang lain.

d. Semakin senang menolong kepada siapa yang membutuhkan pertolongan.

e. Adanya kesediaan memberikan sesuatu yang dibutuhkan orang lain.

f. Semakin mampu bersikap hormat,sopan, ramah dan menghargai orang lain.

Membangun rasa sosial merupakan budaya bangsa yang sudah bertahun-tahun menjadi kebiasaan. Seperti adanya gotong royong, saling bekerja sama dalam mewujudkan kebersamaan. Ini terjadi di perkampungan, lembaga adat yang mengajarkan tentang nilai sosial itu. Semuanya dibangun atas kesadaran bersama dalam membentuk manusia untuk saling membutuhkan antara satu dengan yang lainnya. Dengan begitu akan tercipta suasana kebersamaan dalam hidup ini. Nilai-nilai itu menjadi penting untuk diajarkan pada anak demi keberlangsungan kehidupannya di masa mendatang.

Selain rasa sosial, pendidikan seni tari juga 
memberikan pembelajaran tentang tanggung jawab. Pada pembelarannya, tanggung jawab ini mempunyai peranan yang berarti bagi setiap anak untuk melakukan gerakan tari. Dari mulai anak harus menghafal, melakukan teknik tari yang tepat dan mengekspresikannya. Anak diajarkan pada nilai-nilai yang memberikan rasa tanggung jawab. Tanggung jawab akan apa yang ia lakukan untuk melakukan gerakan tari secara baik. Di samping itu juga, melatih anak untuk melakukan pekerjaan sampai pada titik yang ia lakukan.

Tanggung jawab merupakan nilai karakter yang bisa memberikan pembelajaran bagi anak untuk memahami arti kesadaran. Kesadaran dalam melakukan kegiatan apapun yang berkaitan dengan pribadi maupun untuk orang lain. Baik itu dalam melakukan pekerjaan atau hal-hal yang berkaitan dengan kepercayaan yang diberikan pada anak. Rasa tanggung jawab harus menjadi bagian pembelajaran yang diberikan pada anak. Ini untuk melatih anak agar kepribadiannya semakin baik. Menjadikan anak agar mempunyai peran berarti bagi dirinya maupun dengan lingkungannya.

Di sisi lain, dengan mempunyai rasa tanggung jawab anak akan semakin tumbuh dewasa. Dalam hal ini cara berpikir anak lebih maju, lebih mengutamakan kepentingan yang positif. Kepentingan yang bisa membawa anak untuk berperilaku pada kebaikan. Itulah kenapa nilai karakter yang berkaitan dengan tanggung jawab sangat tepat untuk diberikan. Melalui pendidikan seni tari nilai tanggung jawab diberikan dengan cara-cara yang sangat sederhana yaitu memberikan ruang bagi anak untuk dapat melakukan gerak tari secara baik. Ada semacam penguatan pada kepribadian anak dalam memberikan penampilannya secara maksimal dan itu akan berdampak pada kualitas bentuk yang dipertunjukkan.

\section{Pendidikan Seni Tari dan Kemampuan 4C}

Pendidikan seni tari sebagai pembelajaran di sekolah maupun di lembaga lainnya tentu juga dapat menghasilkan berbagai kemampuan. Tidak hanya terkait dengan kemampuan teknik saja namun juga kemampuan yang lainnya. Kemampuan teknik hanya menghasilkan kualitas gerak saja. Gerak yang sesuai dengan sikap tubuh pada tarian yang ditampilkan. Jadi lebih pada persoalan teknik menari yang baik. Cara yang tepat dalam melakukan gerakan sesuai dengan bentuk tari yang 
dibutuhkan. Inilah kemampuan teknik yang dimaksud, yaitu lebih mengutamakan pada kemampuan gerak saja.

Tentu tidak hanya itu saja dalam menghasilkan kemampuan pada pendidikan seni tari. Pendidikan seni tari diajarkan untuk mendidik anak agar mempuanyai berbagai kemampuan yang kompleks. Kemampuan itu meliputi 4C (community.critikal thinking, colaborasi and creativitas). Melalui kemampuan 4C diharapkan anak banyak memperoleh pengetahuan dari berbagai sisi. Anak tidak hanya sebatas mampu menari tetapi ada hal lainnya yang dapat memberikan sumbangan berarti bagi diri anak. Dengan kemampuan itu anak akan memiliki berbagai ilmu yang tentunya sangat bermanfaat.

Lalu apa keterkaitan pendidikan seni tari dengan kemampuan 4C, tentu ada hubungannya. Dalam tari kelompok misalnya, sudah terbangun komunitas kecil yang semuanya akan berinteraksi dalam membangun bentuk tari. Komunitas kecil ini juga menghasilkan hubungan antar anak untuk menjadi lebih akrab. Ada suatu komunikasi yang dibangun dengan tujuan tertentu. Pada konteks ini, menjadikan tari yang ditampilkan supaya baik.
Komunitas sangat dibutuhkan anak agar belajar tentang hidup bersama. Saling membantu demi terciptanya hasil maksimal dan itu menjadi keinginan kolektif.

Di sisi lain melalui latihan menari anak-anak juga diajarkan tentang adanya komunitas. Dari situlah anak akan bisa memaknai hidup, saling bertemu dengan temannya. Belajar menari bersama tidak saja untuk mampu melakukan gerak yang baik, tetapi dibalik itu semua ada yang lebih berarti yaitu membangun pertemanan. Dengan adanya komunitas memberikan dampak bagi anak untuk bisa bergaul, membangun pertemanan sehingga penting dalam kehidupannya.

Selain komunitas, melalui pendidikan seni tari juga dapat menghasilkan kemampuan berpikir kritis. Ini bisa terlihat ketika anak bertanya tentang bentuk tari yang dipelajari. Tentu anak tidak hanya menari saja, tetapi ingin mengetahui tentang tari yang dilakukan. Apa itu terkait dengan temanya atau teknik gerak yang tepat. Di samping itu juga, keinginannnya mengetahui pengetahuan tentang tari secara umum. Disinilah kemampuan berpikir kritis tumbuh dengan sendirinya, anak bertanya sesuai dengan apa yang ada dalam pikirannya. Ingin mengetahui segala hal tentang 
tari, karena itu bagian dari rasa ingin tahu anak.

Begitulah berpikir kritis tumbuh dalam pendidikan seni tari yang didasari atas kesadaran dalam dirinya. Ingin mengetahui dari segala hal yang berkaitan dengan tari. Ini akan membawa anak pada kemampuan untuk memahami pengetahuan yang diterima. Bertanya pada hal-hal yang tidak dimengerti dan menjadikan anak ingin selalu tahu atau bahkan bisa menjadikan anak untuk lebih kritis. Anak diajarkan pada hal-hal yang belum dipahami atau bisa jadi membuat anak untuk mengkoreksi pada pembelajaran yang kurang tepat. Di sinilah manfaat berpikir kritis yang bisa membuat anak untuk memahami dari apa yang menjadi keinginantahunya.

Kemampuan yang lainnya yaitu kerja sama, pendidikan seni tari tentu sangat berkaitan dengan hal-hal itu. Kerja sama bisa dillihat saat anak-anak berlatih tari kelompok, disitu ada kerja sama dalam membentuk tari. Anak-anak saling memberikan ide dalam membuat formasi pada ruang gerak yang ditampilkan. Ada suatu gagasan diantara mereka yang menjadi pembahasan. Antar anak bisa mengungkapkan idenya dalam memenuhi kebutuhan yang diinginkan. Disinilah kerja sama terlihat, mereka saling melengkapi dalam membangun ide kebersamaan. Dengan begitu akan menghasilkan kesepakatan yang pada akhirnya menghasilkan karya.

Kerja sama merupakan kemampuan yang sangat penting untuk diberikan pada anak. Melalui pendidikan seni tari, anak diajarkan tentang bagaimana membangun kemampuan kerja sama. Tentu ini sangat berarti bagi anak untuk belajar hidup. Saling membutuhkan dalam menghadapi persoalan yang dapat dipecahkan secara bersama. Dari sinilah kemampuan kerja sama menjadi penting. Bagi anak ini merupakan pembelajaran yang bisa membawa kemampuan yang penuh arti. Menjadikan anak untuk bisa saling bekerja sama sebagai hasil dari kemampuan pengalaman belajarnya.

Kemampuan yang lain dari hasil pendidikan seni tari adalah kreativitas. Menumbuhkan kreatifitas merupakan salah satu pembelajaran yang sangat penting bagi anak. Untuk itulah melalui pendidikan seni tari, kemampuan akan kreativitas tumbuh dengan sendirinya. Anak belajar gerak tari yang kemudian dapat memberikan pengalaman tersendiri. Pengalaman dari berbagai gerak yang dipelajari sehingga semua itu bisa menjadi 
pijakan. Pijakan yang dapat membuahkan kreativitas.

Kreativitas dapat dipahami sebagai daya ungkap yang mempunyai nilai kekaryaan. Baik itu hasil dari pijakan yang dipelajari sebelumnya atau menemukan hal-hal baru sebagai daya ungkap. Dari pijakan sebelumnya bisa dikembangkan menjadi bentuk baru sesuai ide atau gagasan. Sedangkan hasil dari temuan baru, merupakan kerja kreatif yang mengeksplor gagasan menjadi bentuk inovatif. Pada konteks pendidikan seni tari, kreatifitas dapat dipahami sebagai ungkapan karya yang berpijak dari sebelumnya yang mengalami pengembangan dan karya yang memang benar-benar baru. Artinya pendidikan seni tari mewadahi anak untuk bereksplor untuk mencari gerak-gerak yang sesuai kebutuhannya.

Bagi anak usia dini kreativitas dapat dipahami sebagai tiruan dari hasil pengalaman belajarnya. Misal anak-anak belajar tari kupu-kupu dan sampai hafal bentuknya. Ketika anak-anak bermain dengan temannya lalu mendengarnya musik kemudian mereka menari maka dari pengalaman belajarnya bisa muncul secara tiba-tiba. Gerak tari kupu-kupu bisa muncul dengan sendirinya sebagai hasil dari proses sebelumnya. Inilah daya tangkap anak usia dini yang masih meniru dari proses pembelajarnnya. Maka kreativitas itu dapat dipahami sebagai daya ungkap yang muncul dari gagasan sesuai dengan tingkat perkembangan anak.

3. Pendidikan Seni Tari, Nilai Karakter, Kemampun 4C dan Revolusi Industri 4.0

Perkembangan jaman yang semakin cepat atau dengan kata lain globalisasi telah menciptakan teknologi yang serba mapan. Teknologi merupakan hasil peradaban yang berpijak dari gagasan baru dan telah memberikan percepatan. Saat ini apa yang menjadi kebutuhan sangat mudah dicapai melalui teknologi. Ini artinya teknologi sangat memudahkan dalam mencapai pada hal-hal yang diinginkan. Begitulah teknologi yang dapat memberikan pelayanan yang serba cepat dan mudah dijangkau.

Melalui teknologi yang serba cepat, maka saat ini dikenal dengan istilah masa revolusi industri 4.0. Revolusi industri 4.0 merupakan hasil dari peradaban yang menciptakan teknologi serba canggih. Ini dibuktikan dengan berbagi produk, baik berupa mesin-mesin pabrik atau alat-alat yang berkaitan dengan kebutuhan. Begitu mudahnya dan sangat cepat teknologi itu digunakan 
dalam memenuhi kebutuhan hidup. Maka kehadirannya sudah menjadi kosumsi publik dan sangat erat dengan kehidupan sehari-hari.

Munculnya revolusi industri 4.0 tidak bisa dibendung karena itu sudah menjadi perkembangan dari peradaban. Peradaban yang membuat tingkat kecanggihan lebih maju dari kehidupan ini. Semuanya tersedia dengan kecepatan yang sangat tinggih sehingga dapat memberikan kepuasan tersendiri. Bagi anak milleneal, saat ini merupakan era yang membuat mereka berhadapan langsung dengan teknologi.

Tentu ada dampak positif dan negatif dalam pada era revolisi industri 4.0. Adapun dampak positifnya adalah akan bertambahnya pengetahuan. Ini akan membuat anak untuk ingin belajar dan dapat memahami tingkat kecanggihan yang muncul. Sedangkan dampak negatifnya, membuat anak akan semakin kecanduan. Menempatkan hasil teknologi digunakan pada hal-hal yang negatif. Misalnya sering anak bermain teknologi tanpa mengenal waktu. Teknologi menjadi segala-galanya bagi diri anak. Misalnya seringnya bermain game on line, plays station tanpa mengenal batas waktu. Setiap hari selalu bermain game di waktu yang kurang tepat. Inilah yang membuat anak terasa diracuni oleh kebutuhankebutuhan yang dapat mengubah perilakunya. Perilaku yang asyik dengan sendirinya tanpa harus membutuhkan orang lain.

Lalu bagaimana pendidikan seni tari yang bisa menghasilkan berbagai karakter dan kemampuan 4C dalam menghadapi revolusi industri 4.0 ini. Sudah barang tentu pendidikan seni tari harus menerima kehadirannya sebagai suatu kemajuan yang tidak bisa ditolak. Pendidikan seni tari justru harus memanfaatkan kemajuan itu sebagai bagian dalam mengembangkan nilai karakter dan kemampuan 4C. Kehadiran revolusi industri 4.0 yang menghasillkan teknologi ini bisa digunakan sebagai bagian dalam mengembangkan pembelajaran. Baik itu terkait dengan nilai karakter maupun kemampun 4C.

Terkait dengan nilai
karakter misalnya yang
menyangkut percaya diri, keberanian, pantang menyerah, rasa sosial dan tanggung jawab. Pertama harus ditumbuhkan rasa percaya diri pada anak untuk menerima kehadiran teknologi sebagai hasil dari revolusi industri 4.0. Kehadirannya tentu harus dimanfaatkan sebagai media yang positif untuk pembelajaran. Dengan demikian dapat menghasilkan anak yang mandiri 
dalam menemukan ilmunya. Anak tidak tergantung pada guru dalam menrima pembelajaran. Misalnya anak belajar tari melalui youtobe, video serta media on line lainnya. Dengan demikian teknologi digunakan sebagai media pembelajaran. Rasa percaya diri harus ditumbuhkan bahwa dengan belajar melalui media teknologi dapat memberikan pengetahuan maupun keterampilan.

Di samping itu juga dengan memanfaatkan media teknologi juga membuat anak mempunyai keberanian. Keberanian akan memanfaatkan media teknologi menjadi pendukung dalam menghasilkan pembelajaran. Anak diajarkan untuk memutuskan terkait dengan pembelajaran yang diterimanya. Melalui pemanfaatan media teknogi anak berusaha untuk melakukan tindakan dalam rangka pencapain ilmu yang diterimanya. Memutuskan secara tepat untuk mendapatkan pembelajaran yang cepat.

Di samping itu juga, melalui media teknologi akan menjadikan anak untuk pantang menyerah. Pada pembelajaran tari misalnya, anak selalu mengulang-ngulang untuk memutar kembali dari video tari yang dimiliki. Setiap saat anak berusaha untuk mencari gerak-gerak yang belum dihafal atau menyesuaikan irama musiknya. Dari situlah akan nampak jiwa pantang menyerah untuk menghafal gerak yang dilihat. Pantang menyerah merupakan nilai karakter yang harus ditumbuhkan agar anak selalu berusaha dalam menghadapi tantangan kehidupan.

Selain itu juga, melalui media teknologi anak diajarkan pada rasa sosial yaitu membangun hubungan antar teman agar tetap terjaga. Pada tarian kelompok, tentu membutuhkan pembelajaran bersama. Lalu bagaimana dengan pemanfaatan media teknologi. Jika salah satu anak mempunyai video tari yang itu sangat berguna dan dibutuhkan teman lainnya, maka dapat di share atau diberikan melalui media teknologi. Itu artinya bahwa teknologi sangat bermanfaat bagi kebersamaan. Membagi secara cepat untuk mendapatkan materi tari yang dapat dipelajari.

Kemudian yang terkait dengan tanggung jawab, pemanfaatan media teknologi dapat memberikan rasa tanggung jawab pada anak. Anak berupaya terus untuk melakukan gerak tari sesuai dengan apa yang dipelajari. Rasa tanggung jawab itu dipenuhi dengan melakukan peniruan terhadap video tari yang menjadi media pembelajaran. Dengan begitu rasa tanggung 
jawab menjadi terpupuk. Keterpupukan tanggung jawab ini terkait dengan kepercayaan diri anak.

Lalu bagaimana pengembangan pendidikan seni tari yang menghasilkan kemampuan 4C di masa revolusi industri 4.0. Kemampuan 4C (community.critikal thinking, colaborasi and creative) merupakan bagian yang perlu ditumbuhkan pada diri anak. Untuk itulah pendidikan seni tari sebagai pembelajaran harus bisa memberikan kemampuan itu pada anak. Misalnya Pemanfaatan teknologi dalam membangun komunitas. Ketika anak belajar menari di suatu sanggar itu bisa membuat komunitas tersendiri. Melalui media teknologi seperti what sApp yang ada di hanp phone anak bisa membuat komunitas baru. Komunitas yang sesuai dengan hobinya. Tentu anak juga bisa membentuk komunitas yang lainnya untuk menjalin pertemanan, baik melalui face book dan istragram.

Selain kemampuan membangun komunitas, anak dituntut berpikir kritis. Yang dimaksud berpikir kritis adalah mampu memilih konten yang berguna dalam menunjang pembelajarannya. Dalam konteks pembelajaran tari anak diharapkan mampu untuk menyaring bentuk tari yang ada di berbagai media sehingga yang dipelajarinya adalah yang benarbenar yang dibutuhkan. Berpikir kritis memberikan dampak positif bagi anak untuk menerima atau tidak menerima segala hal yang masuk dalam diri anak. Jika anak tidak membutuhkan atau itu dianggap tidak mempunyai keuntungan maka tidak akan diterima. Sebaliknya jika itu bisa mendukung dalam pembelajarannya maka akan diterima. Maka posisi teknologi sebagai media penyampai informasi tentu akan menjadi pertimbangan untuk dipakai atau tidak. Semua itu tergantung daya pikir kritis anak untuk menyaringnya.

Berikutnya adalah

Kemampuan kolaborasi yang juga menjadi bagian dalam pendidikan seni tari. . Kemampuan kolaborasi dalam konteks teknologi dipahami sebagai pemanfaatan media yang dipakai untuk tujuan tertentu. Salah satunya adalah digunakan sebagai pendokumentasian. Misalnya anak-anak sedang melakukan pementasan maka perlu alat yang dapat menyimpan hasil tampilannya. Begitu juga dengan latihan menari juga bisa memanfaatkan media itu. Seperti penggunaan HP untuk merekam kegiatan yang dilakukan, baik pada saat tampil maupun proses 
latihan. Semua itu digunakan untuk melihat kembali dari apa yang sudah dilakukan sebelumnya. Seperti keperluan mengevaluasi dari hasil proses latihan maupun tampilan.

Kemampuan yang lainnya dari hasil pendidikan seni tari adalah kreativitas. kreativitas merupakan bagian dalam menghasilkan kemampuan anak secara maksimal. Pada era teknologi ini, kreativitas dapat berpijak dari hasil penglihatan anak tentang berbagai macam bentuk tari. Melalui media on line anak bisa mencari berbagai bentuk tari sesuai kebutuhan yang diinginkan. Dari situlah muncul bentuk-bentuk tari yang menjadi pilihannya. Bagi anak usia dini bentuk tari itu bisa ditiru sebagai pembelajarannya. Sedangkan bagi anak dewasa selain meniru, mereka bisa mengembangkan dalam bentuk tarian baru. Inilah kreativitas yang dapat memunculkan karya-karya baru. Tentu ini sangat berarti bagi anak untuk dapat mengembangkan gagasannya.

\section{SIMPULAN}

Pendidikan seni tari merupakan bagian pembelajaran yang sangat penting bagi anak. Pada proses pembelarannya pendidikan seni tari tidak hanya menghasilkan tentang pengetahuan dan keterampilan saja. Namun juga dapat memberikan pembelajaran yang terkait dengan nilai karakter. Nilai itu meliputi kepercayaan diri, keberanian, pantang menyerah, rasa sosial dan tanggung jawab.

Nilai karakter yang dihasilkan melalui pendidikan seni tari nampak ketika anak belajar menari. Melalui belajar menari anak mampu menghasilkan berbagai karakter yang sangat penting bagi kehidupannya di masa mendatang. Belajar menari tidak hanya mengasah kemampuan yang terkait dengan keterampilan saja, tetapi dibalik itu ada nilai karakter yang yang sang berarti bagi anak.

Selain nilai karakter, pendidikan seni tari juga dapat menghasilkan kemampuan 4C (community.critikal thinking, colaborasi and creative.) pada anak. Ini bisa terlihat ketika proses pembelajaran menari berlangsung. Dari situlah kemampuan anak itu tumbuh dengan sendirinya. Tumbuh atas dasar pembiasan dan kesadaran dalam menghasilkan berbagai kemampuan. Tentu ini sangat baik bagi diri anak sebagai modal dasar dalam kehidupannya.

Pada perkembangannya, pendidikan seni tari yang menghasilkan nilai karakter dan kemampuan 4C tidak bisa lepas dari era revolusi industri 4.0. 


\begin{abstract}
Revolusi ini menghasil teknologi yang serba canggih dan mempunyai kecepatan. Untuk itu pendidikan seni dapat memanfaatkan hasil teknologi sebagai media untuk mengembangkan nilai karakter dan kemampuan 4C pada anak.

Salah satu hasil teknologi itu adalah media on line yang bisa memberikan ruang untuk mengembangkan nilai karakter dan kemampuan 4C. Misal penggunaan hanp phone yang dapat memberikan pengembangan dari keduanya. Baik terkait dengan nilai karakter maupun kemampuan 4C. Teknologi yang sudah menjadi bagian dari kehidupan saat ini, tentu harus benar-benar dimanfaatkan untuk tujuan apapun. Tujuan yang harus mempunyai nilai positif.
\end{abstract}

\section{DAFTAR PUSTAKA}

Asrori, Mohammad. 2007. Psykologi Pembelajaran. Bandung: CV Wacana Prima

Acetylena, Sita. 2018. Pendidikan Karakter Ki Hadjar Dewantara.Malang: Madani Kelompok Intrans Publising

Bertens, K. 2002. Etika. Jakarta:PT Gramedia Pustaka Utama

Mulyani, Novi. 2016. Pendidikan Seni Tari Anak Usia Dini. Yogyakarta: Gava Media

Purwanto, Setyoadi. 2016. Pendidikan Karakter Melalui
Seni. Yogyakarta:Pustaka

Pelajar

Soedarsono. 1972. Jawa dan Bali Dua Pusat Perkembangan Drama Tari di Indonesia. Yogyakarta: Gajah Mada University Press. 